Регіональна хмара публічного управління як складова електронного уряду України

Сергій Кандзюба, Дніпропетровський регіональний інститут державного управління Національної академії державного управління при Президентові України

Впровадження сучасних технологій дозволить отримати максимальний ефект від функціонування системи електронного уряду й подолати технологічну відсталість України від інших держав світу. Розвиток інформаційно-комунікаційних технологій відбувається дуже стрімко, тому ïx дослідження, аналіз і формулювання пропозицій щодо використання є актуальною задачею. Розглянуті теоретичні засади створення регіональної хмари публічного управління, приклади іï використання.

Визначені постачальники хмарних сервісів та інформаційних ресурсів у регіональну хмару: центральні органи влади, регіональні органи влади та IT-компанії. На відмінок від двох перших каналів постачання хмарних сервісів, третій канал бурхливо розвивається у всьому світі і пропонує широкий вибір програмного забезпечення. Найбільш відомими постачальниками програмного забезпечення як послуги (SaaS) є компанії Google i Microsoft.

Розглянуті можливості сервісів Google на двох прикладах - організації колективної роботи публічних службовців за допомогою онлайн-офісу і створення єдиного інформаційно-освітнього простору підготовки та підвищення кваліфікації державних службовців та посадових осіб місцевого самоврядування регіону.

У першому прикладі відзначено, що у більшості українських систем електронного документообігу можливості для організації колективної роботи над проектом документа дуже обмежені. Для вирішення цієї задачі потрібен онлайн-офіс. Можливості сервісів Google, зокрема пакету сервісів G Suite, для організації колективної роботи публічних службовців завдяки наявності онлайн-офісу величезні.

У другому прикладі звертається увага на те, що можливість надавати доступ до корпоративних сервісів поза межами хмари означає, що доступ до навчальних матеріалів освітнього сервісу за необхідністю може бути наданий користувачам, які не мають корпоративного акаунта Google, a мають індивідуальний акаунт Google. Це розкриває широкі можливості щодо залучення публічних службовців, працівників комунальних організацій, установ і підприємств до дистанційного навчання з використанням освітнього сервісу в регіональній хмарі публічного управління.

Запропонована реалізація регіональної хмари публічного управління за допомогою мультихмари.

Ключові слова: електронний уряд, єдиний інформаційно-освітній простір, мультихмара, онлайн-офіс, регіональна хмара публічного управління, хмарні сервіси

\title{
Regional cloud of public administration as a component of the e-government of Ukraine
}

\section{Sergiy Kandziuba, Dnipropetrovsk regional institute for public administration National academy for public administration under the President of Ukraine}

The implementation of modern technologies will allow to get the maximum effect from the functioning of the e-government system and to overcome technological backwardness of Ukraine from other countries of the world. The development of information and communication 
technologies is very rapid, so their research, analysis and formulation of proposals for use is an urgent task. The theoretical bases of creation of regional cloud of public administration, examples of its use are considered.

Suppliers of cloud services and information resources to the regional cloud are identified: central authorities, regional authorities and IT companies. Unlike the first two cloud service delivery channels, the third channel is booming around the world and offers a wide variety of software. The most well-known software vendors as services (SaaS) are Google and Microsoft.

Possibilities of Google services are considered in two examples: organization of public servants' collective work through online office and creation of unified information and educational space for training and raising qualification of civil servants and local government officials of the region.

In the first example, it is noted that in most Ukrainian electronic document management systems, opportunities for teamwork on a draft document are very limited. This requires an online office. Possibilities of Google services, in particular the G Suite, for public servants teamwork due to availability an online office are enormous.

The second example draws attention to the fact that the ability to share corporate services beyond the cloud means that educational materials can be accessed, if necessary, to users who do not have a Google corporate account but have a Google individual account. This opens up great opportunities for involving public servants, employees of communal organizations, institutions and enterprises in distance learning through the use of educational service in the regional cloud of public administration.

The implementation of a regional cloud of public administration with the help of multicloud is proposed.

Keywords: e-government, unified information and educational space, multicloud, online office, regional cloud of public administration, cloud services

\section{Региональное облако публичного управления как составляющая электронного правительства Украины}

Сергей Кандзюба, Днепропетровский региональный институт государственного управления Национальной академии государственного управления при Президенте Украины

Внедрение современных технологий позволит получить максимальный эффект от функционирования системы электронного правительства и преодолеть технологическую отсталость Украины от других государств мира. Развитие информационно-коммуникационных технологий происходит очень быстро, поэтому их исследование, анализ и формулировка предложений по использованию является актуальной задачей. Рассмотрены теоретические основы создания региональной облака публичного управления, примеры ее использования.

Определены поставщики облачных сервисов и информационных ресурсов в региональную облако: центральные органы власти, региональные органы власти и ИТ-компании. На падеж от двух первых каналов поставки облачных сервисов, третий канал бурно развивается во всем мире и предлагает широкий выбор программного обеспечения. Наиболее известными поставщиками программного обеспечения как услуги (SaaS) являются компании Google и Microsoft.

Рассмотрены возможности сервисов Google на двух примерах - организации коллективной работы публичных служащих с помощью онлайн-офиса и создания единого ин- 
формационно-образовательного пространства подготовки и повышения квалификации государственных служащих и должностных лиц местного самоуправления региона.

В первом примере отмечено, что в большинстве украинских систем электронного документооборота возможности для организации коллективной работы над проектом документа очень ограничены. Для решения этой задачи нужен онлайн-офис. Возможности сервисов Google, в частности пакета сервисов G Suite, для организации коллективной работы публичных служащих благодаря наличию онлайн-офиса огромны.

Во втором примере обращается внимание на то, что возможность предоставлять доступ к корпоративным сервисам вне облака означает, что доступ к учебным материалам образовательного сервиса при необходимости может быть предоставлен пользователям, которые не имеют корпоративного аккаунта Google, а имеют индивидуальный аккаунт Google. Это раскрывает широкие возможности по привлечению публичных служащих, работников коммунальных организаций, учреждений и предприятий к дистанционному обучению с использованием образовательного сервиса в региональной облаке публичного управления.

Предложенная реализация региональной облака публичного управления с помощью мультихмары.

Ключевые слова: электронное правительство, единое информационно-образовательное пространство, мультиоблако, онлайн-офис, региональное облако публичного управления, облачные сервисы

\section{Постановка проблем}

$\mathrm{H}$ адання якісних публічних послуг є одним з пріоритетних питань керівництва держави. Про це, зокрема, свідчить Указ Президента України «Про деякі заходи із забезпечення надання якісних публічних послуг» від 4 вересня 2019 р. № 647/2019. В Указі зазначається, що документ ухвалено «з метою утвердження функціонування сервісної держави - держави для громадян і бізнесу, забезпечення належної реалізації прав фізичних та юридичних осіб у сфері надання публічних, у тому числі адміністративних, послуг, створення сучасної інфраструктури, зручних та доступних електронних сервісів для надання таких послуг» [1]. Досягнення цієї мети можливе шляхом розбудови в Україні системи електронного уряду з використанням сучасних інформаційно-комунікаційних технологій. Впровадження саме сучасних технологій дозволить отримати максимальний ефект від функціонування системи електронного уряду й подолати технологічну відсталість України від інших держав світу. Розвиток інформаційно-комунікаційних технологій відбувається дуже стрімко, тому їх дослідження, аналіз 30 i формулювання пропозицій щодо використання $є$ актуальним завданням.

\section{Аналіз досліджень і публікацій.}

Питання впровадження в Україні технологій електронного урядування розглядають О. Васильєва [2], В. Дрешпак [3], О. Карпенко [4], I. Клименко [5], I. Козюpa [6], К. Линьов [7], І. Лопушинський [8], А. Семенченко [9], С. Чукут [10] та ін.

$\mathrm{y}$ вітчизняних дослідженнях у сфері електронного урядування здебільшого зосереджено увагу на розробці загальнометодологічних засад формування системи електронного урядування, питаннях вдосконалення нормативно-правового забезпечення, організації окремих національних інформаційних ресурсів органів державної влади. Разом з тим спостерігається дефіцит досліджень у сфері використання хмарних технологій у публічному управлінні, зокрема, використання мультихмар, хоча в розвинутих країнах ця технологія стрімко набуває популярності.

Метою дослідження $є$ аналіз та вироблення сучасних методологічних підходів до розбудови регіональної хмари публічного управління, реалізованої у вигляді мультихмари. 


\section{Виклад основного матеріалу.}

Регіональна хмара публічного управління - це інтегрований пакет хмарних сервісів (застосунків, додатків) та інформаційних ресурсів, призначений публічним службовцям, а також працівникам комунальних установ, організацій та підприємств регіону. Доступ до сервісів регулюється для різних категорій користувачів відповідно до їх функціональних обов'язків. Крім того, до окремих сервісів та інформаційних ресурсів, за необхідністю, може бути наданий доступ усім жителям регіону.

Вибір регіонального рівня для створення хмари публічного управління не випадковий. Існують три основні типи стратегій держави щодо процесів розбудови інформаційного суспільства та впровадження електронного урядування:

- невтручання держави, при цьому основними рушійними силами $є$ ринкові процеси саморегулювання, саморозвитку та самоорганізації;

- централізованого управління та регулювання з боку держави;

- раціонального поєднання процесів державного управління та саморегулювання (саморозвитку, самоорганізації) [11].

В Україні переважає саморозвиток та самоорганізація без системного дієвого впливу держави, що не відповідає міжнародним вимогам, насамперед, документам всесвітніх самітів.

Стратегія централізованого управління (регулювання) може бути доцільною в специфічних умовах життєдіяльності суспільства та держави, а саме в умовах кризи, надзвичайних ситуацій та особливого періоду. У більшості провідних країн світу застосовується третій підхід, який дає можливість оптимально використовувати ресурси державного та недержавного секторів економіки, сильні сторони кожного з суб'єктів розбудови інформаційного суспільства та впровадження електронного урядування.

Досвід Дніпропетровщини показує, що саме на регіональному рівні сконцентровані найбільш потужні IT-ресурси: центр обробки даних, мережі, програмне забезпечення, фахівці. Усе це складає основу для впровадження і подальшого розгортання регіональних хмарних сервісів.

Постачальниками хмарних сервісів та інформаційних ресурсів у регіональну хмару можуть бути:

- центральні органи влади;

- регіональні органи влади;

- ІТ-компанії.

Розглянемо більш детально кожний 3 цих випадків.

Хмарні сервіси центральних органів влади. У 2016 році Верховна Рада України ухвалила у першому читанні та готувала до другого читання проект Закону України «Про внесення змін до деяких законодавчих актів України щодо обробки інформації в системах хмарних обчислень» (реєстр. № 4302 від 24 березня 2016 р.).

Через несприйняття бізнесом та інститутами громадянського суспільства низки норм та положень законопроекту, які не відповідали національним інтересам України та ухвалення яких створювало загрозу національній безпеці, проходження законопроекту протягом 2016-2019 рр. було заблоковано.

Згідно з вимогами Закону України «Про Регламент Верховної Ради України» законопроекти, ухвалені Верховною Радою попереднього скликання в першому читанні за основу, розглядаються Верховною Радою нового скликання.

На цей час законопроект залишився для розгляду i зареєстрований 29.08.2019 за № 0894 .

Комісія з питань науки та IT вчергове звернулася до ВРУ та запропонувала не допустити його ухвалення та сприяти його відхиленню.

У листі Комісії визначені основні негативні аспекти, що можуть створити загрози інформаційній безпеці та кібербезпеці як складових національної безпеки України.

Навпаки, на цей час для багатьох держав хмарні обчислення - це реальність, повсякденна робота, завдяки якій стає можливим прорив в усіх основних напрямах інформатизації країни і отримання конкурентної переваги у світовому масштабі. Наведемо деякі приклади.

Практика використання хмарних технологій державними організаціями поширена 
всією планетою. Так, Федеральний уряд США почав кілька років тому реалізовувати план перенесення урядових інформаційних систем в хмари, визнавши їх переваги і здатність технологій забезпечити належний рівень безпеки. У січні 2012 р. чиновники США опублікували федеральні вимоги до постачальників хмарних послуг для державних органів, серед яких 170 пунктів стосуються саме забезпечення безпеки.

У Таїланді застосування хмарних технологій дозволило уряду скоротити державні витрати на утримання електронних державних послуг і внутрішніх систем на 30 \%, заявляв ще в 2014 р. глава Агентства у справах електронного уряду країни. «Протягом останніх двох років завдяки хмарним технологіям нам вдалося заощадити на технічному забезпеченні 600 мільйонів бат (майже $\$ 19$ млн.) - це принаймні $30 \%$ економії», - зазначав він. Понад 500 мобільних застосунків різноманітних категорій (транспорт, медицина, освіта, працевлаштування та ін.) на той момент уже зберігалися в державній хмарі.

Сінгапур почав будувати «Електронний уряд 2.0» ще в 2011 р., назвавши цей проект eGov2015. У 2015 році він успішно завершився - тепер громадянам і бізнесу держпослуги поставляються прямо із хмари на смартфони. Уряд Великобританії опублікував в 2011 р. стратегію освоєння хмарних технологій державою, яка зайняла цілих п'ять томів [12].

За даними ENISA (Агентство СС 3 мережевої та інформаційної безпеки), для надання адміністративних послуг або державного документообігу cloud-рішення вже застосовують Італія, Австрія, Словенія, Португалія і Туреччина. Великобританія, Іспанія і Франція не тільки використовують хмарні технології, а й ухвалили стратегію розвитку хмарних сервісів.

G-Cloud створює попит на послуги дата-центрів. Наприклад, у Великій Британії поява урядової хмари дала роботу 700 IT-компаніям [13].

Модель споживання IT-сервісів у форматі послуг SaaS широко поширюється в бізнес-середовищі незалежно від масшта- бів компанії завдяки своїм цінностям і комерційній доцільності.

У всьому світі послуги SaaS особливо популярні з боку державної сфери, промислових компаній і компаній, що займаються торгівлею.

Хмарні сервіси регіональних органів влади.

На сайті Державного агентства $з$ питань електронного урядування України наведена структура системи електронної взаємодії державних електронних інформаційних ресурсів «Трембіта» (https://trembita.gov.ua/ ua/projects/techinfo). Ця система є одним 3 ключових елементів електронного уряду України, отже, іiі структура визначає структуру електронного уряду.

Структура визначає три основні рівні функціонування електронного уряду:

1. Технічний. Його забезпечує мережа Інтернет.

2. Технологічний. Сюди відносяться базові загальнодержавні реєстри і кадастри, система електронної взаємодії «Трембіта», шлюзи обміну даними.

3. Прикладний. Сюди відносяться інформаційні системи органів публічної влади, підпорядкованих їм установ, підприємств та організацій, портали, до складу яких входять різноманітні веб-застосунки.

3 іншого боку, вищерозглянута структура електронного уряду може бути розділена на регіональні складові. Тобто в кожній області може бути створена своя система електронного уряду за вищерозглянутою схемою, яка водночас є фрагментом єдиної загальнодержавної системи електронного уряду. Звичайно, це можливо лише за умови дотримання єдиних стандартів розробки систем.

На практиці часто саме так і відбувається - завдання розвитку мережі Інтернет, формування регіональних фрагментів загальнодержавних реєстрів та кадастрів вирішуються на регіональному рівні. До того ж, дані, які містяться у регіональних фрагментах загальнодержавних реєстрів та кадастрів переважно споживаються також у регіоні. Це обумовлює доцільність створення регіональної корпоративної інформацій- 
ної системи (хмари) публічного управління, яка водночас є складовою загальнодержавної системи електронного уряду.

На сьогодні розподілені корпоративні інформаційні системи створюються за допомогою хмарних технологій. Зокрема, це стосується системи «Трембіта». Дотримуючись єдиних стандартів розробки на регіональному рівні можливо і доцільно розбудовувати відповідний фрагмент електронного уряду України у вигляді регіональної корпоративної хмари публічного управління.

На сьогодні у Дніпропетровській області відбувається формування регіональної корпоративної інформаційної системи, яка є складовою загальнодержавної системи електронного уряду.

До програмного забезпечення, яке зараз використовується в регіоні, відноситься:

- система документообігу;

- система роботи зі зверненнями громадян;

- програмне забезпечення call-центру;

- система надання електронних послуг «Віртуальний офіс»;

- корпоративна пошта та ін.

Хмарні сервіси IT-компаній. На відміну від двох попередніх каналів постачання хмарних сервісів, цей канал бурхливо розвивається у всьому світі і пропонує широкий вибір програмного забезпечення. Найбільш відомими постачальниками програмного забезпечення як послуги (SaaS) є компанії Google i Microsoft. Далі розглянемо можливості сервісів Google на двох прикладах організація колективної роботи публічних службовців за допомогою онлайн-офісу i створення єдиного інформаційно-освітнього простору підготовки та підвищення кваліфікації державних службовців та посадових осіб місцевого самоврядування регіону. Зазначимо, що працювати з сервісами Google можна, використовуючи пакети корпоративних сервісів G Suite (платний), G Suite for Education (безкоштовний для навчальних закладів) або створивши індивідуальний акаунт у публічній хмарі Google (безкоштовно).

У більшості українських систем електронного документообігу можливості для організації колективної роботи над проек- том документа дуже обмежені. Для вирішення цієї задачі потрібен онлайн-офіс. Можливості сервісів Google, зокрема пакету сервісів G Suite, для організації колективної роботи публічних службовців завдяки наявності онлайн-офісу величезні. Всесвітньовідома компанія Google постійно розширюється і створює нові і нові продукти, слідкуючи за світовими тенденціями. Наразі список сервісів налічує більш ніж 40, багато з яких можна використовувати в органах державного управління та місцевого самоврядування, зокрема 3 метою забезпечення електронної взаємодії публічних службовців.

Далі розглянемо варіант використання індивідуального акаунта в публічній хмарі Google.

Основною перевагою програмних продуктів та сервісів Google $€$ те, що більшість 3 них абсолютно є безкоштовні. Деякі з них мають платні розширення та послуги, які зазвичай необхідні лише для професійного використання. Інша перевага - це зручність. Переважна кількість програмних продуктів та сервісів працюють на більшості пристроїв, їх мобільні версії синхронізуються зі стаціонарними. У цьому разі у публічних службовців уся інформація завжди знаходиться «під рукою». Третя перевага перед програмними продуктами інших компаній - це простота використання, взаємозв'язок між собою та великий функціонал.

Для організації спільної роботи важливе значення має сервіс хмарного зберігання даних Google Диск. Дисковий простір на 15 ГБ можна безкоштовно отримати, маючи пошту від Google. Google Диск має безліч зручних функцій, адже, окрім зберігання файлів будь-яких форматів, за його допомогою можна створювати різні документи, наприклад Google Документи, Google Презентації, Google Таблиці, Google Форми.

Усі ці документи мають онлайн-форму, для їх завантаження використовується меню $з$ популярними форматами для перегляду офлайн. Також при створенні або читанні таких документів за допомогою додатків Диску їх можна зберігати для доступу офлайн в оригінальному форматі.

Особливість Диску полягає в тому, що 
існують різні рівні доступу до документів. Можна створити відкриту папку, доступ до якої надати визначеній групі публічних службовців, а можна відкрити доступ за посиланням. У такому разі папка/файл будуть доступні всім іншим групам публічних службовців, хто перейде за цим посиланням. При цьому існує рівень доступу до файлів та каталогів 3 дозволом редагування, коментування та перегляду. Кожен із цих рівнів можна виставити як для визначених користувачів індивідуально, так і для доступу за посиланням. Створення таких папок зручно під час роботи з різними групами публічних службовців (наприклад, у різних проектах), коли необхідно мати певне спільне сховище файлів.

Створення документів онлайн буде ефективнішим та зручнішим, коли над одним проектом працює декілька публічних службовців. При цьому усі співробітники можуть брати участь у створенні документа i бачити, які зміни вносить інший користувач. Якщо ж зміни були внесені раніше, то можна переглянути історію змін. Такі документи зберігаються автоматично, що гарантує те, що вони будуть збережені. Але при роботі в браузері потрібен доступ до мережі Інтернет. Дуже зручним є додавання правок або коментарів, оповіщення про які приходять на Google Пошту публічним службовцям. Правки можна прийняти або відхилити, а на коментарі відповісти іншим співробітникам. Google Диск також зручний для пересилання Google Поштою файлів великих розмірів, які неможливо прикріпити до листа повідомлення.

Використання розглянутих та інших сервісів Google дозволяє створити середовище електронної взаємодії органу публічної влади, комунального підприємства, установи. До того ж, використання платного пакету G Suite дозволяє створити захищений інформаційний простір установи або організації, реалізований у вигляді приватної корпоративної хмари.

Усе сказане про сервіси Google повною мірою відноситься і до пакетів хмарних сервісів конкуруючої фірми Microsoft: Office 365 - платна версія і OneDrive - безкоштовна версія.
Далі розглянемо застосовність хмарних сервісів Google для створення єдиного інформаційно-освітнього простору підготовки та підвищення кваліфікації державних службовців та посадових осіб місцевого самоврядування регіону. Для цього, насамперед, слід визначити групи учасників електронного взаємодії. Можна виділити п’ять груп.

Перша група - замовники освітньої послуги, до неї відносяться: Національне агентство України з питань державної служби, Обласна державна адміністрація, органи місцевого самоврядування. Друга група - слухачі, що навчаються в регіональному інституті Національної академії державного управління при Президентові України. Третя група - слухачі короткотермінових курсів підвищення кваліфікації. Четверту групу складають працівники галузевих ВНЗ - викладачі та адміністрація навчальних закладів. П'яту групу представляють різні розробники електронних освітніх ресурсів, які можуть бути використані при підготовці слухачів. До таких ресурсів відносяться електронні освітні ресурси регіональних інститутів Національної академії державного управління при Президентові України, багатогалузевих українських та зарубіжних навчальних закладів, електронних бібліотек, що надаються безкоштовно або в порядку обміну, мультимедійні освітні ресурси сторонніх розробників.

Функції освітнього сервісу в регіональній хмарі публічного управління можуть бути ефективно реалізовані різними застосунками пакету G Suite for Education.

Застосунок Google Classroom $€$ комплексним рішенням, яке забезпечує всю необхідну функціональність для організації дистанційного навчання. Використовуючи налаштування для цього застосунка, можна забезпечити роботу з ним або лише в корпоративній хмарі, або в корпоративній хмарі та поза ії̈ межами.

Крім того, замість Classroom можна використовувати набір сервісів - Calendar, Drive, Sites. Цей набір також забезпечує необхідну функціональність для організації дистанційного навчання як у корпоративній хмарі, так і поза її межами. До того ж, мож- 
на використовувати різні комбінації цих сервісів та сервісу Classroom. Наприклад, Classroom використовується для створення декількох віртуальних класів - по одному для кожної групи слухачів, а за допомогою сервісу Drive можна створити спільний диск для всіх слухачів, який буде використовуватися як електронна бібліотека.

Можливість надавати доступ до корпоративних сервісів поза межами хмари означає, що доступ до навчальних матеріалів освітнього сервісу за необхідністю може бути наданий користувачам, які не мають корпоративного акаунта Google, а мають індивідуальний акаунт Google. Це розкриває широкі можливості щодо залучення публічних службовців, працівників комунальних організацій, установ і підприємств до дистанційного навчання 3 використанням освітнього сервісу в регіональній хмарі публічного управління.

Наступне важливе питання, яке природно виникає після розгляду каналів постачання, - як об'єднати хмарні сервіси різних постачальників у єдиній регіональній хмарі публічного управління? Це можна зробити використовуючи модель мультихмари.

Мультихмара - модель розгортання, яка допускає використання хмарних сервісів (SaaS), платформ (PaaS) i інфраструктур (IaaS) від безлічі різних провайдерів одночасно і незалежно один від одного. Зазначимо, що під мультихмарою часто мається на увазі не різновид моделі хмарних обчислень, а саме стратегія розміщення і управління корпоративними даними.

У межах мультихмарного оточення компанія може розподіляти робочі навантаження між різними провайдерами, вибираючи у кожного лише ту послугу, яка максимально відповідає вимогам їх окремого сервісу, додатка або іншого завдання. Наприклад, у великих організаціях різні відділи можуть розміщувати частини інфраструктури або додатки у різних хмарних провайдерів. Це автоматично запобігає повномасштабній втраті даних і ситуації, коли збій на стороні постачальника паралізує роботу всієї компанії. Або інший приклад: щоб скоротити час доступу до вашого додатка для користувачів окремих регіонів, логічніше розгорну- ти його у місцевих провайдерів.

Мультихмара $\epsilon$ розвитком гібридної хмари. Гібридна модель передбачає розширення можливостей приватної хмари, розгорнутої на власних серверах компанії, за рахунок ресурсів публічного хмари, а також оркестровку відкритих і приватних хмарних рішень між собою. Як правило, гібридна хмара служить для реалізації додаткових вимог у межах одного робочого навантаження. Наприклад, можна підвищити продуктивність програми за рахунок додавання обчислювальних потужностей відкритої хмари або розширити сховище даних, орендуючи ресурс у провайдера. У мультихмарі різні завдання розподіляються між окремими провайдерами і виконуються незалежно одне від одного. Гібридні рішення можуть бути складовими мультихмари, але не навпаки. Іноді гібридну хмару називають перехідною формою від приватного і публічного - до мультихмари.

Мультихмара дозволяє поєднувати i компонувати хмарні сервіси від різних cloud-провайдерів без їх об'єднання або оркестрації. Тому ефективність роботи в цьому оточенні багато в чому залежить від правильного управління даними. Стежити за роботою хмар, що надаються окремими провайдерами, можна за допомогою хмарних брокерів або через спеціальні платформи (cloud management platforms), що зв'язують хмарні ресурси незалежних провайдерів в єдиний пул. У цьому разі управляти даними можна централізовано - ніби 3 єдиної хмари - через універсальну консоль.

\section{Висновки.}

1. Розбудова системи електронного уряду $є$ складним науково-технічним завданням, вирішення якого потребує використання сучасних інформаційно-комунікаційних технологій і консолідації зусиль усіх органів публічної влади.

2. Створення регіональної хмари публічного управління відповідає третьому типу стратегій держави щодо процесів розбудови інформаційного суспільства та впровадження електронного урядування - раціонального поєднання процесів державного управління та саморегулювання (саморозвитку, самоорганізації). 
3. Постачальниками хмарних сервісів та інформаційних ресурсів у регіональну хмару можуть бути: центральні органи влади, регіональні органи влади, IT-компанії.

4. Перші два з вказаних каналів знаходяться на самому початку свого розвитку. На відмінок від них, третій канал бурхливо розвивається у всьому світі і пропонує широкий вибір програмного забезпечення.

5. Використання хмарних сервісів Google дозволяє швидко і ефективно організувати колективну роботи публічних службовців за допомогою онлайн-офісу, створити єдиний інформаційно-освітній простір підготовки та підвищення кваліфікації державних службовців та посадових осіб місцевого самоврядування регіону, а також вирішити багато інших завдань.

6. Об'єднати хмарні сервіси різних постачальників у єдиній регіональній хмарі публічного управління можна використовуючи модель мультихмари.

\section{БІБЛІОГРАФІЧНІ ПОСИЛАННЯ}

1. Про деякі заходи із забезпечення надання якісних публічних послуг : Указ Президента України від 4 вересня 2019 року № 647/2019. URL: https://zakon.rada.gov.ua/laws/show/ru/647/2019.

2. Васильєва О. І., Євсюкова О. В. Методологічні основи моделювання нормативно-правових важелів надання публічних послуг в умовах розбудови сервісно-орієнтованої держави. Публічне управління та митне адміністрування. 2017. № 1. C. 7-16. URL: http://nbuv.gov.ua/UJRN/vamcudu_2017_1_3.

3. Дрешпак В. Розвиток електронного урядування як напрям державної інформаційної політики України: організаційний аспект. Державне управління та місцеве самоврядування. 2012. Вип. 4. C. 78-87. URL: http:// nbuv.gov.ua/UJRN/dums_2012_4_12.

4. Карпенко О.В., Куйбіда В.С., Наместнік В.В. Цифрове врядування в Україні: базові дефініції понятійно-категоріального апарату. Вісник Національної академії державного управління при Президентові України. Серія : Державне управління. 2018. № 1. C. 5-10. URL: http://nbuv.gov.ua/UJRN/vnaddy_2018_1_3.

5. Клименко I. В. Основні підходи до визначення понять «електронний уряд» та «електронне урядування». Економіка та держава. 2009. № 6. C. 93-96. URL: http://nbuv.gov.ua/UJRN/ecde_2009_6_28.

6. Козюра I. Процеси децентралізації у сфері надання адміністративних послуг. Теоретичні та прикладні питання державотворення. 2018. Вип. 22. С. 132-139. URL: http://nbuv.gov.ua/UJRN/tppd_2018_22_17.

7. Линьов К. О., Линьов В.К, Управління розвитком IКТ-компетентності керівника закладу освіти. Відкрите освітнє е-середовище сучасного університету. 2017. Вип. 3. URL: http://nbuv.gov.ua/UJRN/oeeemu_2017_3_26. 8. Лопушинський I. П. Упровадження електронного урядування в роботу органів виконавчої влади України як вагома складова реформування державної служби. Публічне управління: теорія та практика. 2010. № 2. С. $194-198$.

9. Семенченко А. Механізми державного управління у сфері електронного урядування. Студії з архівної справи та документознавства. 2012. Т. 20. С. 109-113. URL: http://nbuv.gov.ua/UJRN/sasd_2012_20_17.

10. Чукут С. А., Дмитренко В.І. Смарт-сіті чи електронне місто: сучасні підходи до розуміння впровадження е-урядування на місцевому рівні. Інвестиції: практика та досвід. 2016. № 13. C. 89-93. URL: http://nbuv.gov.ua/ UJRN/ipd_2016_13_17.

11. Електронне урядування та електронна демократія: навч. посіб.: у 15 ч. / за заг. ред. А.І. Семенченка, В.М. Дрешпака. Київ, 2017. Частина 1: Вступ до курсу. Концептуальні засади електронного урядування та електронної демократії / [В.Я. Малиновський, Н.В. Грицяк, А.І. Семенченко]. Київ: ФОП Москаленко О. М., 2017.70 с. 12. Государство в облаках. URL: https://www.kommersant.ru/doc/3331200.

13. Госуправление в облаке. URL: https://delo.ua/business/gosupravlenie-v-oblake-295739/.

\section{REFERENCES}

1. Pro deyaki zakhody iz zabezpechennya nadannya yakisnykh publichnykh posluh : Ukaz Prezydenta Ukrayiny vid 4 veresnya 2019 roku № 647/2019 [On some measures to ensure the provision of quality public services: Presidential Decree from September, 42019 No. 647/2019]. Retrieved from https://zakon.rada.gov.ua/laws/show/ru/647/2019 [in Ukrainian]. 2. Vasyl'yeva, O. I., \& Yevsyukova, O. V. (2017). Metodolohichni osnovy modelyuvannya normatyvno-pravovykh vazheliv nadannya publichnykh posluh v umovakh rozbudovy servisno-oriyentovanoyi derzhavy [Methodological bases of modeling of legal levers of provision of public services in the conditions of service-oriented state development]. Publichne upravlinnya ta mytne administruvannya - Public management and customs administration, 1, 7-16. Retrieved from http://nbuv.gov.ua/UJRN/vamcudu_2017_1_3 [in Ukrainian]. 
3. Dreshpak, V. (2012). Rozvytok elektronnoho uryaduvannya yak napryam derzhavnoyi informatsiynoyi polityky Ukrayiny: orhanizatsiynyy aspekt [Development of e-governance as a direction of the state information policy of Ukraine: organizational aspect.]. Derzhavne upravlinnya ta mistseve samovryaduvannya. - Public administration and local government, 4, 78-87. Retrieved from http://nbuv.gov.ua/UJRN/dums_2012_4_12 [in Ukrainian].

4. Karpenko, O.V., Kuybida, V.S., \& Namestnik, V.V. (2018). Tsyfrove vryaduvannya v Ukrayini: bazovi definitsiyi ponyatiyno-katehorial'noho aparatu [Digital Governance in Ukraine: Basic Definitions of the Conceptual and Categorical Apparatus]. Visnyk Natsional'noyi akademiyi derzhavnoho upravlinnya pry Prezydentovi Ukrayiny. Seriya : Derzhavne upravlinnya - Herald of the NAPA under the President of Ukraine. Regional administration and local government, 1, 5-10. Retrieved from http://nbuv.gov.ua/UJRN/vnaddy_2018_1_3 [in Ukrainian].

5. Klymenko, I. V. (2009). Osnovni pidkhody do vyznachennya ponyat' «elektronnyy uryad» ta «elektronne uryaduvannya» [Basic approaches to the definition of eGovernment and eGovernment]. Ekonomika ta derzhava, 6, 93-96. Retrieved from http://nbuv.gov.ua/UJRN/ecde_2009_6_28 [in Ukrainian].

6. Kozyura, I. (2018). Protsesy detsentralizatsiyi u sferi nadannya administratyvnykh posluh [Decentralization processes in the field of administrative services]. Teoretychni ta prykladni pytannya derzhavotvorennya - Theoretical and applied issues of state-building, 22, 132-139. Retrieved from http://nbuv.gov.ua/UJRN/tppd_2018_22_17 [in Ukrainian].

7. Lyn'ov, K. O., \& Lyn'ov, V. K. (2017). Upravlinnya rozvytkom IKT-kompetentnosti kerivnyka zakladu osvity [Managing the development of the ICT competency of the head of the educational institution]. Vidkryte osvitnye e-seredovyshche suchasnoho universytetu - Open Educational E-Environment of Modern University, 3. Retrieved from http://nbuv.gov.ua/UJRN/oeeemu_2017_3_26 [in Ukrainian].

8. Lopushyns'kyy, I. P. (2010). Uprovadzhennya elektronnoho uryaduvannya v robotu orhaniv vykonavchoyi vlady Ukrayiny yak vahoma skladova reformuvannya derzhavnoyi sluzhby [Implementation of e-governance in the work of the executive bodies of Ukraine as a significant component of civil service reform]. Publichne upravlinnya: teoriya ta praktyka - Public Administration: Theory and Practice, 2, 194-198 [in Ukrainian].

9. Semenchenko, A. (2012). Mekhanizmy derzhavnoho upravlinnya u sferi elektronnoho uryaduvannya [The mechanism of public administration in the field of e-governance]. Studiyi z arkhivnoyi spravy ta dokumentoznavstva - Studies of Archival Affairs and Records Keeping, 20, 109-113. Retrieved from http://nbuv.gov.ua/UJRN/sasd_2012_20_17 [in Ukrainian].

10. Chukut, S. A., \& Dmytrenko, V.I. (2016). Smart-siti chy elektronne misto: suchasni pidkhody do rozuminnya vprovadzhennya e-uryaduvannya na mistsevomu rivni [Smart City or E-City: Modern Approaches to Understanding E-Government Implementation at the Local Level]. Investytsiyi: praktyka ta dosvid - Investment: Practice and Experience, 13, 89-93. Retrieved from http://nbuv.gov.ua/UJRN/ipd_2016_13_17 [in Ukrainian].

11. Malynovs'kyy, V.YA., Hrytsyak, N.V., \& Semenchenko, A.I. (2017). Vstup do kursu. Kontseptual'ni zasady elektronnoho uryaduvannya ta elektronnoyi demokratiyi [Admission to the course. Kontseptualni zasady elektronnoho uryaduvannya ta elektronnoyi demokratiyi]. Elektronne uryaduvannya ta elektronna demokratiya - E-governance and e-democracy. A.I. Semenchenko, V.M. Dreshpak (Eds.). Kyiv: FOP Moskalenko O. M. [in Ukrainian].

12. Hosudarstvo v oblakakh [State in the clouds]. Retrieved from https://www.kommersant.ru/doc/3331200 [in Russian]. 13. Hosupravlenye $v$ oblake [Government in the cloud]. Retrieved from https://delo.ua/business/gosupravlenie-voblake-295739/ [in Russian].

\section{Кандзюба Сергій Павлович}

Кандидат технічних наук, доцент Дніпропетровський регіональний інститут державного управління Національної академії державного управління при Президентові України 49044, Дніпро, вул. Гоголя, 29

\section{Kandziuba Sergiy}

Ph.D. Technical Sciences, Assoc.Prof.

Dnipropetrovsk Regional Institute for Public Administration National Academy for Public Administration under the President of Ukraine 29, Gogol Str., Dnipro, 49044, Ukraine

Email: admingsuite@dridu.dp.ua

Цитування: Кандзюба С. П. Регіональна хмара публічного управління як складова електронного уряду України. Аспекти публічного управління, 2019. Т. 7, № 12 . С. 28-37.

Citation: Kandziuba, S.P. (2019). Rehionalna khmara publichnoho upravlinnia yak skladova elektronnoho uriadu Ukrainy [Regional cloud of public administration as a component of the e-government of Ukraine]. Public administration aspects, 7 (12), 28-37. 